\title{
Influencing Purchasing Positioning - Deriving a Model Based on External Factors
}

\author{
Jens-Andreas Barth \\ Faculty of Management, Comenius University, Bratislava, Slovakia
}

Email address:

jensabarth@arcor.de

\section{To cite this article:}

Jens-Andreas Barth. Influencing Purchasing Positioning - Deriving a Model Based on External Factors. Journal of Business and Economic Development. Vol. 3, No. 1, 2018, pp. 11-16. doi: 10.11648/j.jbed.20180301.12

Received: September 28, 2017; Accepted: November 24, 2017; Published: December 20, 2017

\begin{abstract}
Strategy, Employees, Organization, Method and Tools, Processes and Systems can be named as the internal factors which determine organizational performance. Embedded in a corporate organization and interfering with market players there seem to exist further factors, which need to be considered. Since the end of last century corporations experienced economically critical situations, e.g. global finance crisis, war in Iraq, resource scarcity showed enormous impact on global economy and forced even best positioned purchasing organizations to design and implement counter measures to increase their efficiency and effectiveness. Besides significant market disturbance principal market approaches and the interface to corporate indicate further factors. This paper examines which external factors besides the above explained internal factors influence the positioning of a purchasing organization, as the initial analysis step for a cost optimization program. Based on a literature research 4 external influencing factors, a so called 4-Corner-Model will be introduced, subsequently per deductive reasoning typical challenges exposed and counter measures derived. Though internal factors create efficiency and effectiveness, external determine how internal factors should be designed and applied. Thus in order to holistically examine purchasing positioning an analysis of external factors is essential as cost optimization projects often miss their intended goals due to the fact, that purchasing positioning is not carried out properly and wrong conclusion are drawn. The outcome of this paper will help decision makers to understand the real cause of purchasing performance level based on external factors to subsequently design a target oriented approach of purchasing and cost optimization projects.
\end{abstract}

Keywords: Purchasing Positioning, External Factor, Efficiency, Effectiveness, Cost Optimization

\section{Introduction}

Aim of the paper and hypothesis

Many factors can influence the performance level of a purchasing organization. In order to strategically understand the impact of factors, these factors should be structured. Barth [1] introduced Strategy, Employees, Organization, Method and Tools, Processes and Systems, which can be named as internal factors, as the organization can configure these factors to a certain extent. If looked at an organization isolated from its environment, these factors could serve as the only influencing parameters. Actually, embedded in a corporate environment, interacting with market players and participating in a global economy there seem to be further factors that need to be considered.

Especially, when the performance level in terms of savings (output of the organization) does not meet C-level (executive board) expectation, which equals a low effectiveness, the need for a cost optimization program rises. In order to improve the effectiveness (e.g. savings = output), basically the efficiency of an organization requires improvement.

Programs can be run by internal or external consultancies or experts. Strategy consultancies cover all aspects of purchasing topics, but there are also smaller ones, who are specialized in certain areas. The approaches followed differ between consultancies. But not all initiated programs run successfully. The risk is aware at C-Level, that's why some corporations try to run a program on their own or create a healthy mix of Consultancy, external specialists and own sources. Costs associated with an optimization project can quickly reach several Millions. 
Table 1. Costs to run a cost down program with consultancies.

\begin{tabular}{lllll}
\hline Program size & Team set up (\# people, year) & Approx. Project costs, year & FTE assigned by Customer & Potential Savings (1-3 years) \\
\hline Small & $2-3$ & $1 \mathrm{~m} €$ & 0,5 & $5-15 \mathrm{~m} €$ \\
Medium & $4-6$ & $2 \mathrm{~m} €$ & 1,0 & $10-30 \mathrm{~m} €$ \\
Large & $9-11$ & $3 \mathrm{~m} €$ & 1,5 & $15-50 \mathrm{~m} €$ \\
\hline
\end{tabular}

Source: Author

Program cost compose not only of consultancy fees, but also employees assigned, exceeded time frames and subsequently capacities occupied, delayed or even lost savings and finally loss of reputation within corporation. Interestingly approaches successfully implemented at one corporation may fail at another. This could be due to the fact that an initial analysis of the positioning of a purchasing organization was not conducted accurately and influencing external factors were out of scope.

Thus it is crucial besides the understanding of the internal factors to consider external factors as well to carry out the actual positioning precisely.

The author is experienced in industrial purchasing, with a career path as employee in automotive industry, consultancy and nowadays running a small consultancy company, focusing on cost optimization. $\mathrm{He}$ has participated, collaborated and lead several cost reduction programs and has high business interest to successfully implement and run cost reduction programs.

It is the task of the decision maker to determine, if the suggested approach is best fit for corporation. It requires a high level of experience to come to a conclusion. Unfortunately cost reduction programs are not run on a regular basis, thus in general decision makers suffer from a lack of experience.

The outcome of this paper is intended to help decision makers on customer as well as on consultancy side to identify and consider external factors as influencing parameters for a holistic analysis of purchasing positioning. A properly carried out positioning will enable for target oriented approach of purchasing and cost optimization projects to minimize risk of failure and waste of resources.

\section{Methodology and Research Design}

During writing this paper multiple methods were applied. The investigation started with an accumulation of necessary information by an executed internet and literature research of typical external factors from available consultancy information, journals and expert literature. Subsequently the gained information was qualitatively analysed and compared with knowledge based facts to deduce 4 key factors as representative external factors, establishing a so called 4corner-model of influencing external factors of a purchasing organization. There after applied discussion and logical reasoning of typical challenges caused by external factors, detailing and deduction of counter measures to overcome challenges per factor. Finally conclusions are drawn based on synthesis of knowledge.

\subsection{Challenges for Purchasing from External}

Embedded in a corporate organization and interfering with market players there seem to exist further factors, which need to be considered. Since the end of last century corporations experienced economically critical situations, e.g. global finance crisis, war in Iraq, resource scarcity which showed enormous impact on global markets and forced even best positioned purchasing organizations to design and implement counter measures to increase their efficiency and effectiveness. Besides significant economical disturbance principal market approaches and the interface to corporate indicate further factors.

These external factors can be divided into those, which take effect to the enterprise at a whole and thus interacting purchasing indirectly (e.g. crisis in economy, changed market conditions through competition lead to changed market approach and subsequently adjusted purchasing strategy), and those, which are corporate related.

Corporate organizational set up and interdepartmental purchasing involvement and embedding are enterprise inherent factors and as a frame work surrounding purchasing. These factors are again influenced by market and economy as is valid for all corporate divisions but are still influencing purchasing from an outside view.

Next chapter will in detail expose typical challenges coming from external factors, starting with factor economy.

\subsection{Economy}

Crisis shake economy severely, especially if happening on a global basis. Though a crisis can be of very different nature. Natural catastrophes as the volcanic eruption of the Eyjafjallajökull in Iceland 2010 as explained by Globalisierung-Fakten [8] showed far-ranged impact to Iceland and Europe in ecology, health and economy, particularly to touristic and aviation industry. According to Eiselin [5] an eruption of the volcano Katla on Iceland is predicted for this year and will possible cause similar impacts. Interestingly a crisis can in contrary also rise business. Welt-N24 [20] points out, that many tourists nowadays join Iceland for watching volcanos.

Oil is the crucial resource for global economy. In their recent meeting at Algier, the representatives of OPEC concluded to reduce the delivery volume by 750.000 barrel a day according to Weinzierl [19], which lead to a short term price increase of 5,3\% per barrel, long term price impacts will depend on adherence to this conclusion by members.

Currencies represent the strength of an economy. Exchange rates stand for a value price ratio measured in price 
of home currency against quantity of foreign currency, according to Gabler Wirtschaftslexikon [17]. For the US president election in November 2016 Zitelmann [22] predicted different scenarios of US\$ vs. $€$ exchange rate depending on the election of a candidate.

Especially the Mexican Peso is suffering from Donald Trump's statements to build a wall between the US and Mexico. North Mexico is characterized by automotive industry and exports among others in the US. But the currency recovered immediately by $2 \%$ after the second TV debate with Clinton explained the Wirtschaftswoche [21].

Focus Money [7] announced implication of the finance crisis in 2008 were predicted insolvencies in 2009 over and about of 35.000 , equaling $10-15 \%$ indicating a potential loss of accounts receivable of almost 44 billion euros.

Regardless if environmental disaster, fluctuating resource prices or restricted availability of goods and services, fluctuation of currencies or global finance crisis with impact on sales (fall in demand, price decline), enterprises have to react and especially purchasing has to keep up with crisis consequences. It appears, that crisis tend to happen more often meaning in shorter periods and to be quite intense. In a global and netted world that means, that the effects become more drastically: faster impacts result in shorter response times and less planning reliability. Therefore companies require instruments of coverage and risk management.

Though classic instruments to control quality and prices are not sufficient anymore. Instead new ways of risk management are mandatory, as the success of an enterprise increasingly depends on external factors, which cannot be influenced. Thus instruments to identify upcoming threats and emergency plans to initiate mitigating actions are needed to ensure reaction and steering to ensure security supply as recommended by Feldmann [6].

\subsection{Market}

A purchasing department usually works on the one hand on the internal interface with affiliated departments in a manufacturing environment like engineering, production, quality or in a service related environment with e.g. marketing, IT or personnel division. On the other hand, on the external interface, the supply chain needs to be managed.

Regardless service or production related demand carrier, depending on the market segment (e.g. market leadership or trendsetter, follower, low cost driver) participants will have a different market approach and subsequently manage supply chains differently.

In automotive typical market segments are luxury, upper, middle or small class or sports car which define brand image and market positioning.

According to Schulze [16] profitable market leadership can be achieved in various dimensions, e.g. advanced technologies, design or services. Market leadership in segment implies trend setting and focus in respective dimensions and is perceived as innovative while customers are willing to pay a surplus compared to less innovative perceived products. Follower products realize in general lower prices and normally offer less innovation. (e.g. AUDI brand's positioning "lead by technology" and its products design imply technical leadership and enables for premium prices compared to e.g. FIAT or RENAULT, which can rather be perceived as lower priced entry brand). Hence, in an emotional product market as automotive it is elementary for market leadership to manage dedicated innovation towards brand's positioning.

Borden [3] carried out in his research, that it is essential to create a marketing mix, which is based on product, price, promotion and place (4 Ps) to produce a profitable enterprise. This model is explicitly explained in light of actual literature by Khan [12]. Keller [13] explains in his article that customers associate brand imagery with marketing mix and evaluate product performance against price, promotion and place (e.g., in the $80^{\text {th }}$ AUDI changed its market appearance moving from an old style to technology related brand image, change in market perception took a decade and lead to a technology perceived brand). Kotler et al [14] underlines long term customer relationship is founded on quality and fair pricing.

Riaz and Asif [15] created a 4 step model linking Marketing Mix and Branding together. First step is identification of customer's needs based on the four Ps. In the second step named Meaning, Branding is linked to tangible and intangible properties. Response as third step implies customer's judgement and feelings about brand's performance. Finally customer relationship is established based on customer's response.

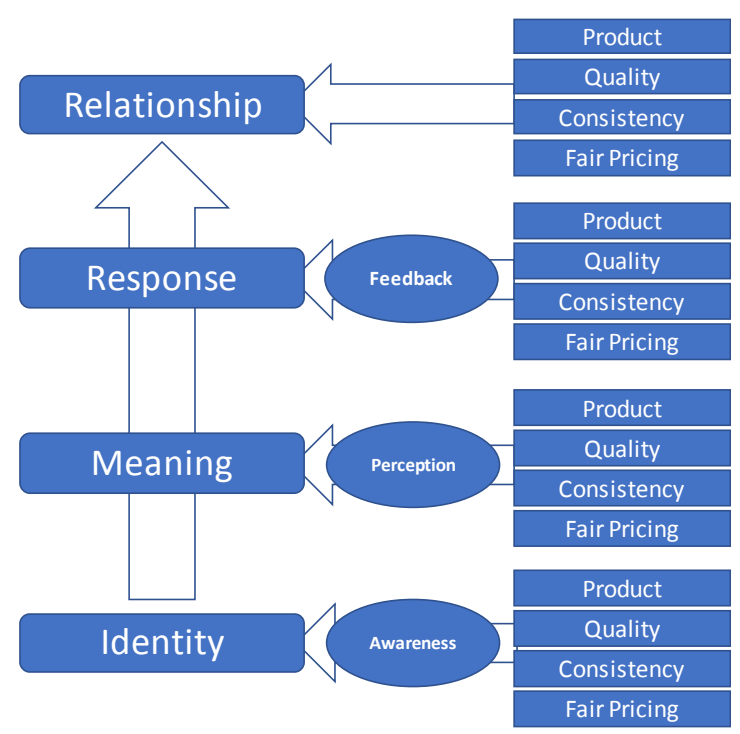

Figure 1. Model: linking Marketing Mix to Brand Building Process, source: Author.

All steps are linked to the 4 Ps (Marketing mix) so that finally 4 Ps substantially define Brand positioning.

According to the above introduced model it is mandatory for a profitable enterprise to understand customer's need and how product features suit customer's imagery and expectation for a long term relationship as key features. These product features need clear definition in order to 
develop and fit customer's perception. Deductive new ideas and innovation have to support defined key product features to help creating tangible customer relationship and to help brand positioning towards market leadership.

The challenge for purchasing lies in managing its supply chain towards the market needs of the enterprise: ensure stability of prices, excellence supplier marketing to access new technologies, disposability of goods and services, early warning measures and emergency plans for quick recovery. This requires close cooperation and netting with the above mentioned affiliated departments and a supply chain, that is designed to suit expectations of end customer and requirements of the market the enterprise participates in in terms of product make up, innovation and quality.

\subsection{Organization}

The organizational set up can be viewed from two perspectives: within the organization and from outside at the organization. At this point the organizational set up of the entire enterprise which cooperates with purchasing stands in the focus and we have a look at corporate organization from a purchasing perspective.

It is mainly important, that also corporate organizational set up allows cross functional cooperation and team approach to enable living processes across departmental borders. A holistic matrix model is a prerequisite (this links to the purchasing organization, which as an internal factor can be adjusted by purchasing itself and from there end have to ensure proper living processes across the departmental interface). Especially in the company size of SMEs purchasing is not yet fully integrated. The challenge for these purchasing organizations is to really embed purchasing in the entire structure, like in the automotive industry.

Consultancy Targus [18] estimated reporting line to top management as extremely crucial for success of purchasing and that a representative should be part of the management team at $\mathrm{C}$-level to participate and actively create internal decision processes in terms of a "voice of purchasing" and as part of the management process. Sometimes purchasing reporting line is not established to top management. Instead purchasing is linked to engineering or finance and suffers from a lack of strategic influence. According to a survey conducted in 2015 published by the Industrieanzeiger [11] only $50 \%$ of the purchasing leaders report to $\mathrm{C}$-level.

Purchasing leaders need to convince top management to link or even anchor their position at top management level in order to participate and influence business decisions.

\subsection{Purchasing Involvement and Embedding}

The meaning of purchasing embedding comprises corporate activities besides organizational framework which allow involvement of purchasing.

Besides the organizational structure described above further elements of cooperation and communication according to Bräuer [2] enable purchasing involvement: e.g. cross departmental process flow, cross functional staff meetings, frequent cross functional decision meetings. Even if corporate organizational structure allows integration of purchasing (e.g. matrix organization, cross departmental process flow), there is no guarantee of full embedded cooperation.

Hagelar et al [9] defined based on a survey conducted at a SME, that added value of purchasing for the company's competitive advantage is determined by alignment between governance of purchasing activities and context of the company. "This reasoning implies a level of internal alliance between boundary-spanning functions like marketing and sales, and purchasing." Unfortunately cross boundary involvement of purchasing is not for given and the level in industry ranges from poor to professional.

Höveler [10] described the need for organizational and personal hurdles to overcome in order to achieve a so called "smart purchasing organization" in the sense of the above mentioned boundary-spanning alliance (see figure 2).

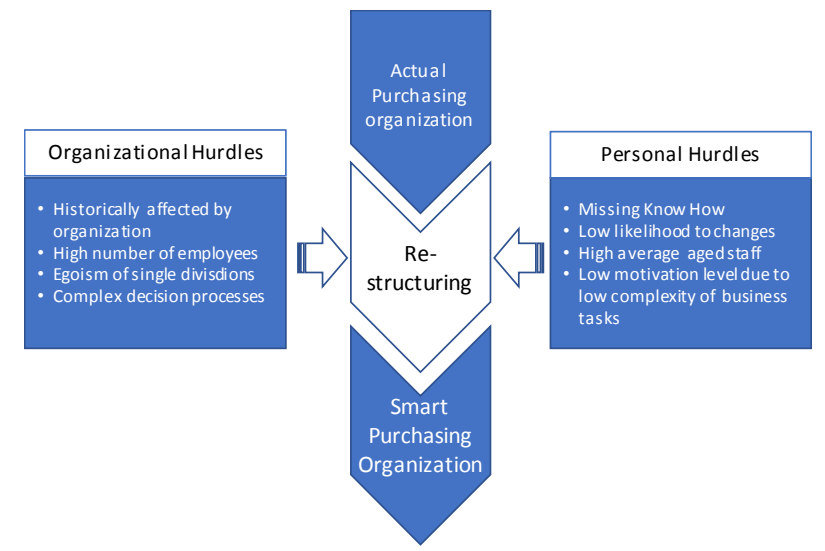

Figure 2. Hurdles to overcome for a smart purchasing organization, source: Author.

The challenges to overcome lie among others in egoism of individual departments, historic affected organizations, demographic structure with high average age.

Purchasing leaders should be encouraged to take up the chance to convince their management by showing additional value potentials: e.g. negotiation prowess, strong ethics, supplier qualification expertise and passion for risk management according to Dominick [7], in case of optimized embedding and early involvement.

\section{Result}

This paper amended the set of internal factors, as introduced by Barth [1], by external factors. Last named are examined in detail as economy, market, corporate organization and embedding. External factor corporate organizational set up has to be distinguished from the internal factor "organization", as it covers corporate structure in which the internal factor is linked to. Corporate organizational set up and purchasing involvement and embedding are enterprise inherent factors at corporate level and as a frame work surrounding purchasing. The external 
factors show a dependency among each other. From a hierarchy point of view the factors corporate organization and embedding are partly influenced by market and economy as well. The model could therefore also serve to indicate input factors for other divisions. The 4 factors compose a model which is named 4-corner model. The identified 4 factors surround a purchasing division in a satellite style.

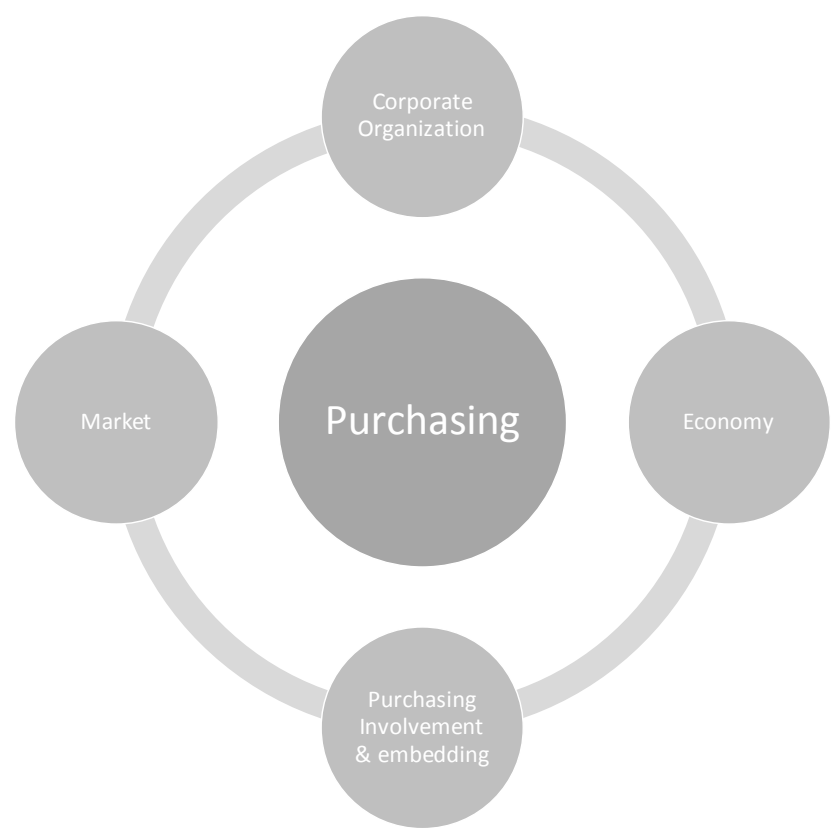

Figure 3. Four-corner Model, external factors of purchasing, source: Author.

The model displays purchasing placed in the center influenced by 4 external factors of which Market and Economy are corporate independent factors whereas organization and involvement and embedding are conditionally manageable by corporate.

The factors are furthermore utilized to describe a set of typical challenges a purchasing division is facing per factor. Based on the examined typical challenges associated with each factor exemplary dedicated set of counter actions was deduced, which summarizes potential fields of action for an optimization program:

1. Implement early warning and risk management system

2. Develop integrated supply chain towards (customer) market needs

3. Anchor Purchasing reporting line at top management

4. Ensure Purchasing early involvement and crossdepartmental embedding

The examined set of factors qualify decision makers to execute structured analysis of purchasing positioning. Dependent of the occurrence of weakness counter actions should be selected and applied in the respective area.

\section{Study Limitation and Conclusion}

There are a lot of parameters which can impact a purchasing organization. The aim of this paper was to classify factors, which comprehensible impact the performance level (output) of a division from outside and which seem to be eligible to help analyze purchasing positioning. Sources like consultancies partly do not provide detailed insights about approaches and hide analysis process steps or offer analysis as a general initial service without naming the approach precisely. This attitude could be owed by the fact, that consultancies are in competition among each other and do not want to spread their knowledge. This attitude underlines the necessity of a sound and holistic positioning understanding. The factors carried out serve primarily in the automotive and machinery sector, where global market conditions apply. Nevertheless industries with similar market approach could benefit as well from the findings.

In order to improve the level of performance these factors need to be analyzed at an early stage. In a subsequent step the internal factors (as introduced in a separate paper) should be evaluated together with these external factors, which forms a holistic picture of purchasing positioning. A four step process should be followed:

1. Analysis of 4 external factors starting with the corporate inherent factors (Corporate organizational, purchasing involvement and embedding), amending with corporate independent factors (Economy, Market)

2. Deduction of challenges and counter measures

3. Analysis of internal factors and deduction of counter measures

4. Consolidation of counter measures (external and internal factors)

Based on the precise initial analysis of purchasing positioning, target oriented counter measure should be identified. By adhering to the above introduced process, an efficient cost optimization program with a minimum sacrifice of resources will be ensured.

\section{References}

[1] Barth J. A., (2016), "How to successfully run a cost reduction program in industrial purchasing" Proceedings of the $15^{\text {th }}$ international Business Scientific conference fpr phd students and young researchers, ISBN: 978-80-87325-08-7, 21-22 April 2016, Slovak Republic, Bratislava, 365-376

[2] Bräuer, A. (2004), Solutions Sourcing, Strategien und Strukturen interorganisationaler Wertschöpfungssysteme, Deutscher Universitäts-Verlag, 1. Auflage

[3] Borden N. (1964), the Concept of Marketing Mix. Journal of Advertising Research, 2, 387-394

[4] Dominick C. (2011), Next level Purchasing, How to Justify early purchasing involvement, Retrieved October 28, 2016], http://www.nextlevelpurchasing.com/articles/earlypurchasing-involvement.php

[5] Eiselin S.(2016), Vulkan Katla, Airlines blicken bang nach Island, [Online], [Retrieved October 25, 2016], http://www.aerotelegraph.com/airlines-blicken-bang-nachisland-ausbruch-vulkan-katla-befuerchtet 
[6] Feldmann C. (2015), Einkauf vor gewaltigen Herausforderungen, [Online], [Retrieved October 25, 2016], https://www.bme.de/feldmann-einkauf-vor-gewaltigenherausforderungen-1315/

[7] Focus Money Online 2009, "die bitteren Folgen der Finanzkrise", [retrieved March 2016], http://www.focus.de/finanzen/boerse/finanzkrise/pleitewelledie-bitteren-folgen-der-finanzkrise_aid_402762.html

[8] Globalisierung-Fakten, Vulkanausbruch in Island, [Online], [Retrieved October 25, 2016], https://www.globalisierungfakten.de/folgen-der-

globalisierung/naturkatastrophen/vulkanausbruch-in-island/

[9] Hagelaar G., Staal A., Holman R., Walhof G. (2014), The Nature of Embedded Purchasing Activities in SMEs: results from a Dutch multiple case study, Working paper WP 131 for the 24th IPSERA conference, Amsterdam 2015

[10] Höveler B. (2016), Einkaufsoptimierung, der Weg zur smarten Einkaufsorganisation, [Online], [Retrieved October 28, 2016], https://www.hoeveler-holzmann.com/veroeffentlichungen/dieaktuellsten/news-detail/der-weg-zur-smarteneinkaufsorganisation/\#

[11] Industrieanzeiger (2015), Personalbarometer 2015, Wie die Stecknadel im Heuhaufen, [Online], [Retrieved October 28, 2016],

http://industrieanzeiger.industrie.de/management/personal/wie -die-stecknadel-im-heuhaufen/

[12] Khan, M. T. (2014), The concept of "Marketing Mix and its Elements", (A Conceptional Review Paper), International Journal of Information, Business and Management, Vol. 6, Issue 2

[13] Keller, K. L. (2013), Strategic Brand Management (4 th Edition), Harlow, Pearson Education

[14] Kotler G. Armstrong G. Saunders J. Wong V.,(2005), Principles of Marketing (Fourth European Edition), Upper Saddle River, Prentice Hall Inc
[15] Riaz W., Asif T. (2012), "Marketing mix not branding", Asian Journal of Business and Management Sciences, pg. 43-52

[16] Schulze G. (2012), "What are the risks and opportunities of being a trendsetter or fast follower?", [Online], [Retrieved June 24, 2016], http://managementism.com/2012/what-are-the -risks-and opportunities-of-being-a-trendsetter-or-fastfollower

[17] Springer Gabler Verlag (Herausgeber), Gabler Wirtschaftslexikon, Stichwort: Strategie, [Online], [Retrieved October 20, 2016] http://wirtschaftslexikon.gabler.de/Archiv/3172/strategiev11.html

[18] Targus (2011), Die Rolle des Einkäufers, Organisation, Potentialnutzung und Erfolgsmessung, [Online], [Retrieved October 18, 2016], http://www.targusconsulting.de/wpcontent/uploads/2012/10/Targus-A4-Einkaufsbroschuere.pdf

[19] Weinzierl S., (2016), Technik und Wirtschaft für die deutsche Industrie, Ölpreise steigen, OPEC drosselt Erdölförderung, [Online], [Retrieved October 25, 2016], https://www.produktion.de/nachrichten/unternehmenmaerkte/opec-drosselt-erdoel-foerderung-260.html

[20] Welt N24, Jetzt sorgt der Eyjafjallajökull für gute Geschäfte, [Online], [Retrieved October 25, 2016], https://www.welt.de/reise/nah/article141658219/Jetzt-sorgtder-Eyjafjallajoekull-fuer-gute-Geschae

[21] Wirtschaftswoche, Devisen, US-Wahlkampf beflügelt den Peso, [Online], [Retrieved October 27, 2016], http://www.wiwo.de/finanzen/boerse/devisen-us-wahlkampfbefluegelt-den-peso/14663694.html

[22] Zitelmann R. (2016), Dollarkurs nach US-Wahl, warum der Dollar bei Trump und Sanders fallen und bei Cruz steigen wird, [Online], [Retrieved October 25, 2016], http://www.wallstreet-online.de/nachricht/8490312dollarkurs-us-wahl-dollar-trump-sanders-fallen-cruz 